NATIONAL LABORATORY

\title{
REPORTED ENERGY AND COST SAVINGS FROM THE DOE ESPC PROGRAM
}

\section{December 2011}

\section{Prepared by} John A. Shonder, Bob Slattery and Erica Atkin

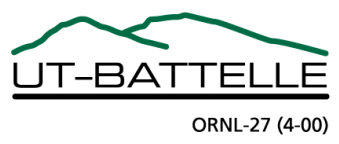




\title{
DOCUMENT AVAILABILITY
}

Reports produced after January 1, 1996, are generally available free via the U.S. Department of Energy (DOE) Information Bridge.

Web site http://www.osti.gov/bridge

Reports produced before January 1, 1996, may be purchased by members of the public from the following source.

\author{
National Technical Information Service \\ 5285 Port Royal Road \\ Springfield, VA 22161 \\ Telephone 703-605-6000 (1-800-553-6847) \\ TDD 703-487-4639 \\ Fax 703-605-6900 \\ E-mail info@ntis.gov \\ Web site http://www.ntis.gov/support/ordernowabout.htm
}

Reports are available to DOE employees, DOE contractors, Energy Technology Data Exchange (ETDE) representatives, and International Nuclear Information System (INIS) representatives from the following source.

Office of Scientific and Technical Information

P.O. Box 62

Oak Ridge, TN 37831

Telephone 865-576-8401

Fax 865-576-5728

E-mail reports@osti.gov

Web site http://www.osti.gov/contact.html

This report was prepared as an account of work sponsored by an agency of the United States Government. Neither the United States Government nor any agency thereof, nor any of their employees, makes any warranty, express or implied, or assumes any legal liability or responsibility for the accuracy, completeness, or usefulness of any information, apparatus, product, or process disclosed, or represents that its use would not infringe privately owned rights. Reference herein to any specific commercial product, process, or service by trade name, trademark, manufacturer, or otherwise, does not necessarily constitute or imply its endorsement, recommendation, or favoring by the United States Government or any agency thereof. The views and opinions of authors expressed herein do not necessarily state or reflect those of the United States Government or any agency thereof. 
Energy and Transportation Science Division

REPORTED ENERGY AND COST SAVINGS FROM THE DOE ESPC PROGRAM

John Shonder

Bob Slattery

Erica Atkin

December 2011

Prepared by

OAK RIDGE NATIONAL LABORATORY

Oak Ridge, Tennessee 37831-6283, managed by

UT-BATTELLE, LLC

for the

U.S. DEPARTMENT OF ENERGY

under contract DE-AC05-00OR22725 


\section{EXECUTIVE SUMMARY}

The objective of this work was to determine the realization rate of energy and cost savings from the Department of Energy's Energy Savings Performance Contract (ESPC) program based on information reported by the energy services companies (ESCOs) that are carrying out ESPC projects at federal sites. Information was extracted from 134 Measurement and Verification $(\mathrm{M} \& \mathrm{~V})$ reports to determine reported, estimated, and guaranteed cost savings and reported and estimated energy savings for the previous contract year. Because the quality of the reports varied, it was not possible to determine all of these parameters for each project.

For 133 of the 134 projects, there was sufficient information to compare estimated, reported, and guaranteed cost savings. For this group, the total estimated cost savings for the reporting periods addressed were $\$ 95.7$ million, total reported cost savings were $\$ 96.8$ million, and total guaranteed cost savings were $\$ 92.1$ million. This means that on average:

- ESPC contractors guaranteed $96 \%$ of the estimated cost savings,

- projects reported achieving $101 \%$ of the estimated cost savings, and

- projects reported achieving $105 \%$ of the guaranteed cost savings.

For 129 of the projects examined, there was sufficient information to compare estimated and reported energy savings. On the basis of site energy, estimated savings for those projects for the previous year totaled 5.371 million MMBtu, and reported savings were 5.374 million MMBtu, just over $100 \%$ of the estimated energy savings. On the basis of source energy, total estimated energy savings for the 129 projects were 10.400 million MMBtu, and reported saving were 10.405 million MMBtu, again, just over $100.0 \%$ of the estimated energy savings. 


\section{INTRODUCTION}

Among the most widely used vehicles for implementing energy savings performance contract (ESPC) projects in the federal government are the ESPCs administered by the U.S. Department of Energy's (DOE's) Federal Energy Management Program (FEMP). DOE ESPCs are indefinitedelivery, indefinite-quantity (IDIQ) contracts designed to make ESPCs as practical and costeffective a tool as possible for agencies to use. These "umbrella" contracts are competitively awarded to energy service companies (ESCOs) who have demonstrated their capabilities to provide energy projects to federal customers. The general terms and conditions are established in the IDIQ contracts, and agencies implement projects by awarding task orders to the DOE ESPC ESCOs. Using IDIQ contracts, agencies can implement ESPC projects in far less time than it takes to develop stand-alone ESPC projects. Since 1998, federal agencies have used DOE ESPCs to award task orders for 269 projects and install more than $\$ 2.4$ billion worth of energy improvements.

The objective of this report is to determine the realization rate of savings from the DOE ESPC program based on a review of the M\&V reports produced by all DOE-FEMP ESPC projects that were in the performance period as of October 3,2011. Information was extracted from the reports to develop a database that includes estimated and reported energy savings by fuel type, and estimated, reported, and guaranteed cost savings for each energy conservation measure (ECM) in each of the ongoing projects. The database was then used to determine fundamental information about the program such as

- the ratio of reported to guaranteed cost savings,

- the ratio of reported to estimated cost savings, and

- the ratio of reported to estimated energy savings.

\section{DATA COLLECTION AND EXTRACTION}

The first step in the data collection process was to determine exactly how many projects were in the performance period. As of October 3, 2011, DOE's list of awarded DOE ESPCs (maintained at http://www1.eere.energy.gov/femp/pdfs/do awardedcontracts.pdf contained 269 projects. The more recently awarded projects were either still in construction or still in the first year of the performance period, so that no M\&V report had yet been produced. Some older projects had already completed the performance period or had been terminated for other reasons. We determined that there were 134 projects that had produced at least one M\&V report during the year preceding October 3, 2010. These 134 projects formed the study population, and their most recent $\mathrm{M} \& \mathrm{~V}$ reports provided the data source for this report.

The periods covered by the annual reports have various start dates depending on when the project's performance period began; however, the average start date is 10/11/2009 and the average end date is 10/9/2010. The contract year of the reports ranges from year 1 to year 11 . Table 1 presents the distribution of reporting years.

As the $M \& V$ reports were collected, information was extracted from them to populate a database that contains a separate record for each project, and for each project, the following information for each ECM: 
- The technology category of the ECM (these are specified in Attachment J-3 of the "Attachments to the IDIQ Contract," linked at http://www1.eere.energy.gov/femp/pdfs/g eneric_idiq_espc_contract.pdf)

- The M\&V method used (FEMP option A, $\mathrm{B}, \mathrm{C}$, or D)

- Estimated energy savings by fuel type (electricity, natural gas, oil, steam, etc.)

- The units of the estimated energy savings (kWh, therms, MMBtu, etc.)

- Reported energy savings by fuel type

- The units of the reported energy savings

\begin{tabular}{|c|c|}
\hline $\begin{array}{c}\text { Table 1. Contract years of the M\&V } \\
\text { reports received }\end{array}$ \\
\hline Contract year & Number of reports \\
\hline 1 & 14 \\
2 & 10 \\
3 & 16 \\
4 & 12 \\
5 & 5 \\
6 & 20 \\
7 & 11 \\
8 & 21 \\
9 & 12 \\
10 & 7 \\
11 & 5 \\
\hline
\end{tabular}

- Estimated cost savings from (1) reduced energy and utility bills, and (2) reduced operations and maintenance (O\&M) and repair and replacement (R\&R) costs

- Reported cost savings from (1) energy savings and (2) O\&M and R\&R savings

The database also includes the guaranteed cost savings for the reporting period. Typically the guaranteed cost savings are not broken down by ECM; instead the ESCO guarantees a dollar amount for the entire project for each contract year.

The quality of the $134 \mathrm{M} \& \mathrm{~V}$ reports examined varied widely, and many were lacking some of the information listed above. For example, some reports were missing the estimated cost savings. In these cases it was sometimes possible to obtain the missing information from the TO schedules for the project (also called H schedules or DO schedules in older projects). These schedules provide a concise listing of the important technical and financial aspects of the project. They are part of the final proposal and the task order, and DOE collects them separately and maintains them in a central database.

In particular, schedule TO-1 lists estimated and guaranteed cost savings by contract year. If there have been no modifications to the contract, the estimated and guaranteed savings listed in the $\mathrm{M} \& \mathrm{~V}$ report should correspond to the estimated and guaranteed savings listed in the TO schedules for that particular contract year. ${ }^{1}$ To fill in missing information, it was assumed that if the guaranteed savings listed in the annual report matched the guaranteed savings listed in the TO-1 schedule for the corresponding contract year, then the estimated savings for the year were as listed in schedule TO-1. Likewise, for reports that did not list guaranteed savings, it was assumed that if the estimated cost savings listed in the $M \& V$ report matched the estimated cost savings listed in schedule TO-1 for the corresponding contract year, then the guaranteed cost savings for that year were the guaranteed cost savings listed in schedule TO-1.

Other reports were missing information on estimated energy savings. The estimated energy savings are a function of the ECMs installed and assumptions made about equipment efficiency, operating hours, weather, and other variables. The estimated energy savings are generally the same for each year of the contract. If no modifications are made to the contract, the estimates do

\footnotetext{
${ }^{1} \mathrm{TO}$ schedules list costs and savings by contract year, and M\&V reports usually include the contract year in their title, for example, Fox Army Health Center: Year 3 Measurement and Verification Report,
}

October 1, 2003-September 30, 2004. 
not change. The estimated energy savings appear on schedule TO-4 for each ECM, and they are used, along with the utility rates and escalation rates specified in the contract, to develop the estimated cost savings for each year of the contract that are listed in schedule TO-1. In the case of missing information on estimated energy savings, it was assumed that if the estimated cost savings listed in the $\mathrm{M} \& \mathrm{~V}$ report matched the estimated cost savings listed in schedule TO-1 for the corresponding contract year, then the estimated energy savings were as listed in schedule TO4.

Many of the projects were found to have been modified in some way since award. In fact, in over a third of the 134 projects examined, the annual guaranteed cost savings listed in the M\&V report were different from the guaranteed savings listed in the TO-1 schedule for the corresponding contract year. In these cases, the figure presented in the $M \& V$ report was assumed to be correct, but it would have been preferable to have a contract document to verify the information in the $M \& V$ report. Some $M \& V$ reports included copies of the applicable TO schedules as an appendix. Having copies of the TO schedules that apply to each M\&V report would make the results for the evaluation more robust by allowing more of the missing information to be filled in.

\section{COST SAVINGS}

Although the primary objective of an ESPC project is to reduce energy use, the most important issue contractually is cost savings, which the ESCO guarantees on an annual basis. Energy use reductions are usually the largest source of the cost savings, but savings can also come from reduced demand, improved power factor (which sometimes results in lower utility rates), and reduced water use. Reduced O\&M and R\&R costs are another major source of savings in ESPC projects.

\subsection{Reported vs. Guaranteed Cost Savings}

Altogether it was possible to determine reported and guaranteed cost savings for 133 of the 134 reports received. The total annual guaranteed cost savings for the 133 projects for the periods covered was $\$ 92,165,222$, and the total reported cost savings was $\$ 96,840,275$. In the aggregate, reported cost savings were $105 \%$ of the guaranteed cost savings.

In 12 of the 133 projects, the reported annual cost savings were equal to the guaranteed cost savings. In these projects, M\&V Option A was used for all of the savings. In the remaining 121 projects, the total reported cost savings was $106 \%$ of guaranteed cost savings, and 112 of these 121 projects reported cost savings exceeding the guaranteed cost savings by an average of $9 \%$.

Table 2 shows the percentage of guaranteed cost savings across all projects in the data set subject to each M\&V Option.

Cost savings shortfalls were reported in 9 of the 121 projects that did not appear to use Option A for all ECMs. The shortfalls range from 3\% to $66 \%$ of the annual guaranteed savings, with the average being $27 \%$ of the annual guaranteed cost savings. In seven of the nine cases, the

Table 2. Percentage of guaranteed cost savings verified by $M \& V$ options $A, B, C$, and $D$ for 133 ongoing DOE ESPC projects.

\begin{tabular}{cc}
\hline $\begin{array}{c}\text { M\&V } \\
\text { Option }\end{array}$ & $\begin{array}{c}\text { Percentage of guaranteed } \\
\text { cost savings }\end{array}$ \\
\hline A & $73 \%$ \\
B & $16 \%$ \\
C & $2 \%$ \\
D & $9 \%$ \\
\hline
\end{tabular}


shortfall was resolved through a reduced payment to the ESCO. In the remaining two cases, the $\mathrm{M} \& \mathrm{~V}$ reports claim that the shortfall was due to an action on the part of the agency and was not the ESCO's responsibility. Agency sites experiencing shortfalls are contacted bi-annually by Oak Ridge National Laboratory to review progress in resolution of outstanding project issues as part DOE-FEMP's ongoing technical support services within the ESPC program.

It is notable that for the group of 133 projects, $79.3 \%$ of the reported annual cost savings were due to reduced utility costs, and $20.7 \%$ were due to O\&M or R\&R savings, all of which were stipulated.

Figures 1 and 2 illustrate the graphic logic used in figures 3, 5, 6, and 7 to show estimated, guaranteed, and reported cost and energy savings, including savings shortfalls and savings exceeding the guarantee.

Figure 1 depicts a project with annual guaranteed cost savings of $\$ 50,000$, represented on the left side of the graphic. The right side of the graphic illustrates the results of the annual M\&V report, which showed savings of only $\$ 40,000$ and a savings shortfall of $\$ 10,000$. On the right side of Fig. 1, the bar is shifted downward so that a portion of it falls below the horizontal axis to represent the magnitude of the shortfall (in red). The bar remaining above the horizontal axis represents the reported savings, shown in yellow. The total height of the bar, red plus yellow, represents the guaranteed savings of $\$ 50,000$.

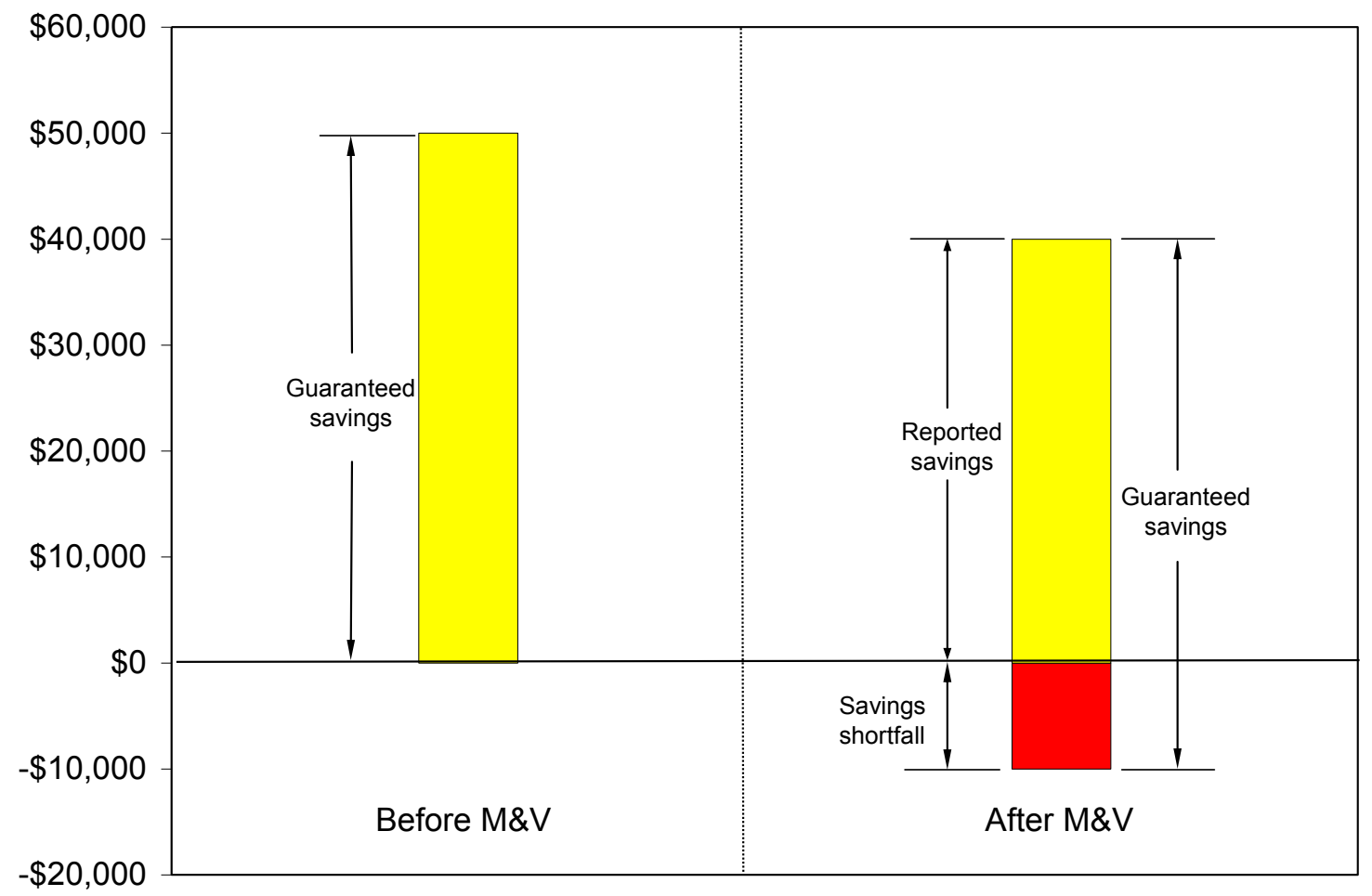

Fig. 1. Guaranteed and reported savings for a project with a savings shortfall.

Figure 2 illustrates how the figures 3, 5, 6, and 7 show reported savings exceeding guaranteed or estimated savings. Here annual guaranteed savings are again $\$ 50,000$, but the $M \& V$ report shows a savings greater than $\$ 50,000$, and the bar from the left side of the figure moves upward on the 
right side by the amount of the surplus, which is shown in blue. The height of the yellow bar, which represents the guaranteed savings, does not change. The combined height of the yellow and blue bars represents the reported savings.

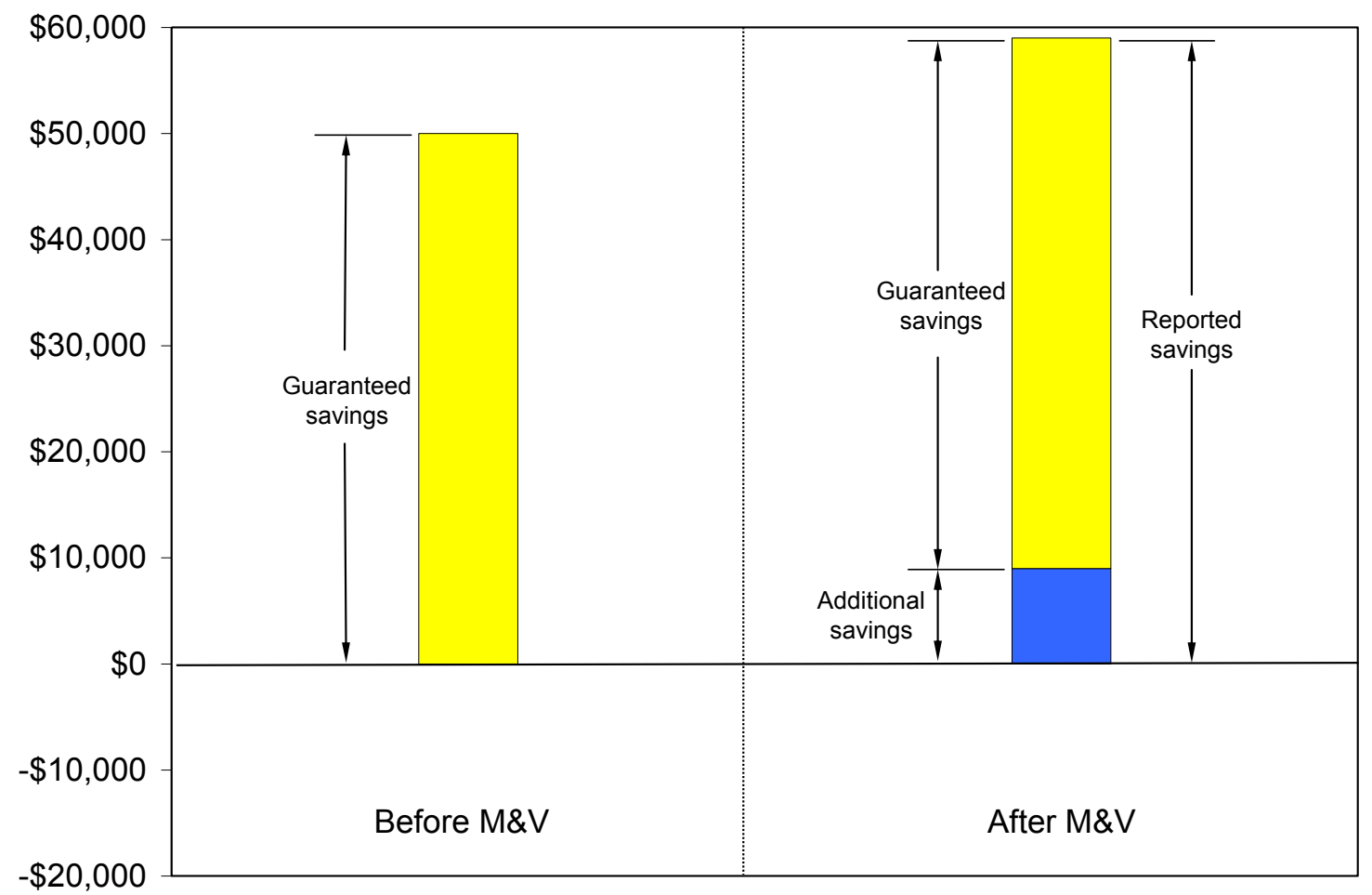

Fig. 2. Guar anteed and reported savings for a project in which cost savings exceeds the guar antee.

Using the scheme illustrated in figures 1 and 2, Fig. 3 presents the annual cost savings, along with shortfalls and reported savings exceeding the guarantee, as reported in the most recent M\&V reports for the 133 DOE ESPC projects analyzed. The projects are arranged in descending order of reported annual cost savings.

One fact immediately evident from Fig. 3 is the large range in the amount of cost savings delivered by the projects: the largest is reporting more than 100 times the cost savings of the smallest. This means that program averages can be dominated by the performance of a small number of large projects. In fact, one of the larger projects is seen to be reporting $171 \%$ of its guaranteed cost savings. This large savings does affect the program-wide average, but not overwhelmingly. When this project is removed from the data, the ratio of reported to guaranteed savings falls from $105.0 \%$ to $104.5 \%$. 


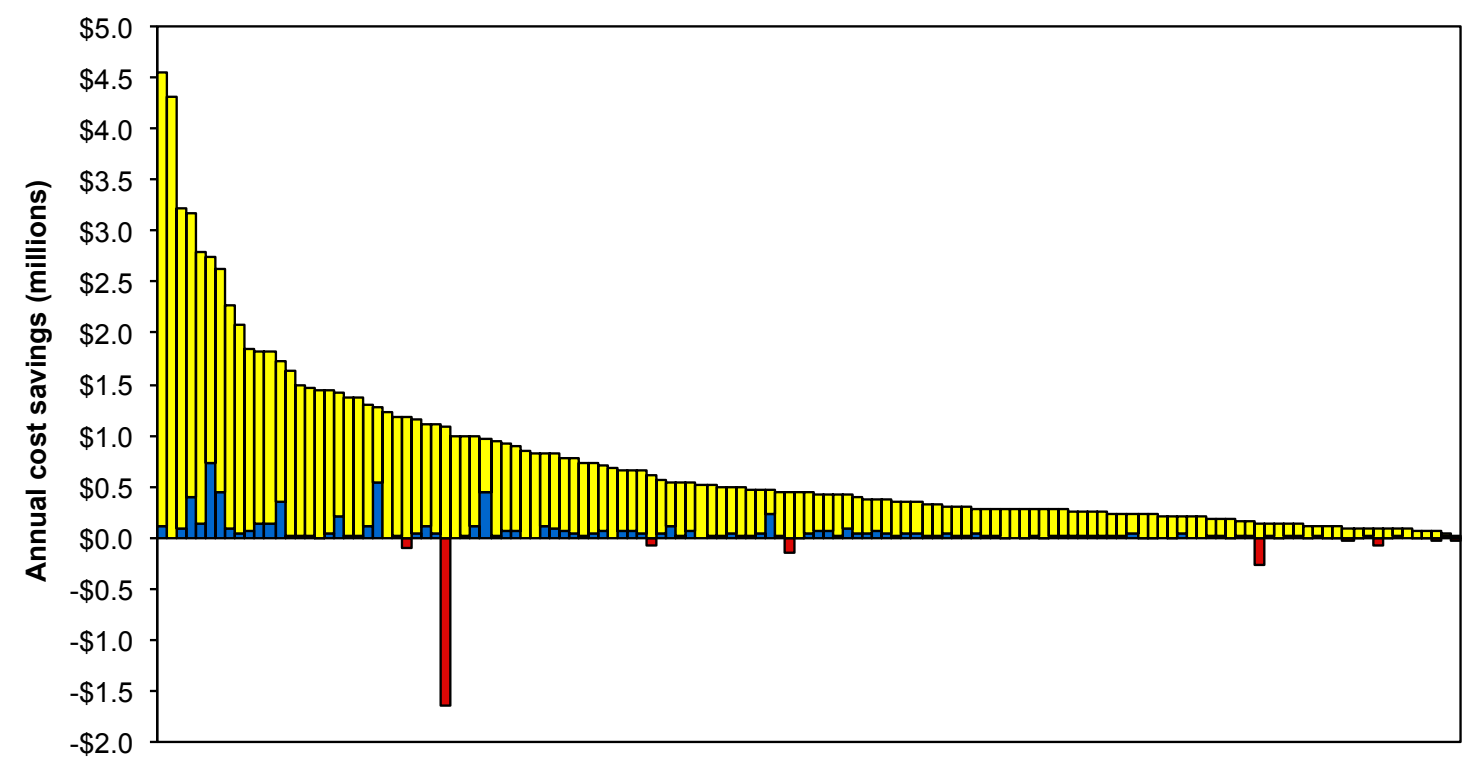

Fig. 3. Annual cost savings from 133 ongoing DOE ESPC projects Cost savings exceeding the guarantee are shown in blue, cost savings shortfalls are shown in red. Where no shortfall occurs, the yellow bar is the amount of the guarantee. Where a shortfall occurs, the amount of the guarantee is the sum of the heights of the yellow and red bars.

Figure 4 presents the same information as Fig. 3 but in a different way: Here the bars represent the percentage of annual guaranteed cost savings reported in the annual $\mathrm{M} \& \mathrm{~V}$ reports. The bars are ordered from highest to lowest percentage of annual guaranteed cost savings. The message is the same, however: The majority of projects report cost savings greater than the guaranteed savings, and only a few projects had cost savings shortfalls.

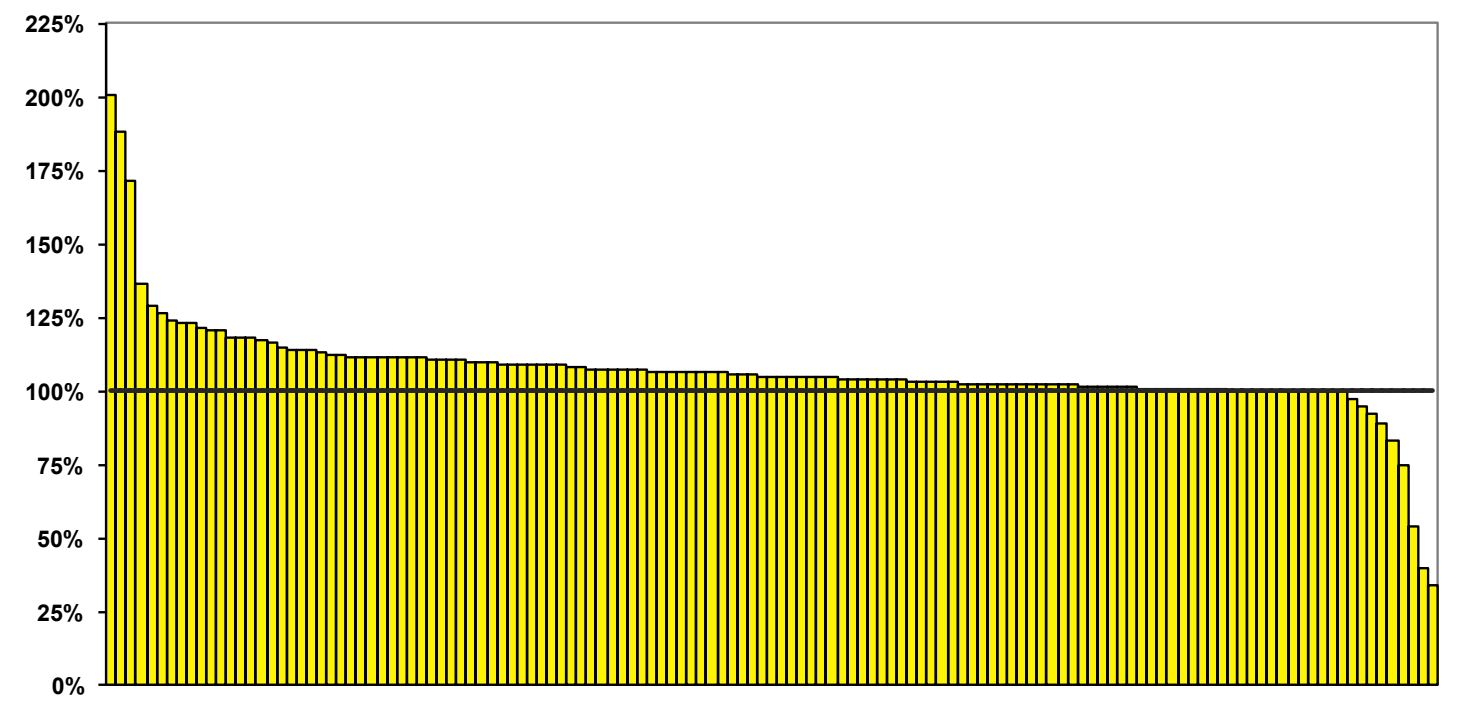

Fig. 4. Percentage of guaranteed annual cost savings reported in 133 ongoing DOE ESPC projects 


\subsection{Reported vs. Estimated Cost Savings}

ESCOs use engineering models to estimate project energy savings, and then use contract utility rates and escalation rates to estimate cost savings for each year of the contract. The annual estimated (or "proposed") cost savings are included in each project task order on schedule TO-1, and should be included in the M\&V reports. As noted in Sect. 3, if estimated cost savings were not provided in the M\&V report, it was possible to extract the information from schedule TO-1, but only if the contract had not been modified since award, because only the award TO schedules (and not contract modification documents) were available for all projects. In all, it was possible to determine estimated and reported cost savings for the same group of 133 projects identified previously.

For these 133 projects, the total estimated and reported cost savings for the periods reported on were $\$ 95,738,954$ and $\$ 96,840,275$ respectively. Thus in the aggregate, reported cost savings were $101.2 \%$ of the estimated cost savings. As stated previously, the total guaranteed cost savings for the 133 projects were $\$ 92,165,222$. Dividing the guaranteed savings by the estimated savings shows that ESCOs guaranteed an average of about $96 \%$ of the savings estimated for the reporting period.

Figure 5 shows the amount by which the reported cost savings exceeded or fell short of the estimated savings, in a manner analogous to Fig. 3. The projects are arranged in descending order of reported savings.

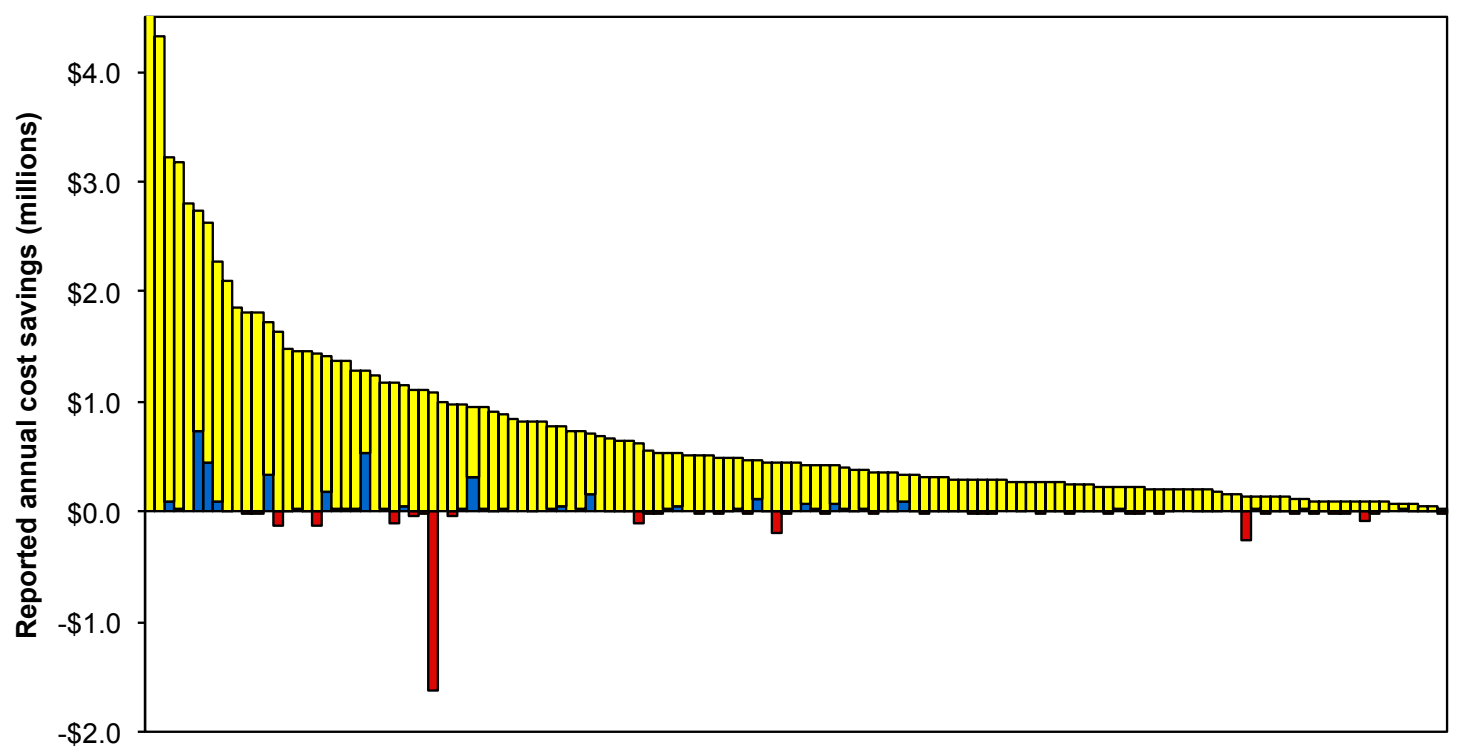

Fig. 5. Reported and estimated annual cost savings from 133 DOE ESPC projects Reported cost savings above the estimated amount are shown in blue, and reported savings below the estimated amount are shown in red. Where reported cost savings equals or exceeds the estimated savings, the height of the yellow bar is equal to the estimated savings. Where reported cost savings is less than the estimated amount, the estimated savings is equal to the height of the yellow and red bars combined. 


\section{ENERGY SAVINGS}

Annual M\&V reports track energy savings as well as cost savings, since one of the primary motivations for implementing DOE ESPC projects is to meet energy use reduction goals. Energy savings are not guaranteed, but the ESCO estimates the energy savings that will occur in each reporting period, uses those savings to estimate cost savings, and guarantees some percentage of that amount. The annual $M \& V$ report should present the energy savings realized during the period, as determined by the methods described in the $\mathrm{M} \& \mathrm{~V}$ plan.

Some of the $M \& V$ reports examined were missing information on energy savings. As with cost savings, in some cases it was possible to determine the estimated energy savings from the TO schedules. Where the estimated energy savings were missing, if the guaranteed cost savings in the $\mathrm{M} \& \mathrm{~V}$ report was equal to the guaranteed savings listed on schedule TO-1 for the corresponding contract year, it was assumed that the estimated energy savings was as listed in schedule TO-4. Furthermore, it was sometimes possible to determine reported energy savings when this information was missing - if the reported cost savings was equal to the estimated cost savings listed in schedule TO-1, then it was assumed that the reported energy savings for the period was equal to the estimated cost savings listed in schedule TO-4.

\subsection{Site vs. Source Energy Savings}

It is customary in the federal government to report energy savings on a site basis, counting electricity savings at 3,412 Btu per $\mathrm{kWh}$, and adding in other fuel savings in Btu. This is problematic for ECMs such as combined heat and power plants that offset the purchase of grid electricity through using fuel on site (usually natural gas), because these plants typically increase site energy use, though they reduce overall energy use and cost. DOE's guidance on Section 502(e) of Executive Order 13123 was followed in these cases. The guidance credits the site energy use by $8,438 \mathrm{Btu}$ for each $\mathrm{kWh}$ of avoided electricity use to account for the reduction in source energy use.

We determined the reported and estimated energy savings for the reporting period for 129 of the 133 annual reports. On a site energy basis, the estimated energy savings for the 129 projects was $5,371,462 \mathrm{MMBtu}$, and reported energy savings was 5,374,522 MMBtu, or $100.06 \%$ of the estimated savings. With the exclusion of a sizable shortfall in one project evident in Figure 5, the ratio of reported savings to estimated savings is $101.9 \%$. This is very close to the ratio of reported to estimated cost savings for these projects, which is $101.2 \%$.

Since the total project investment for the 129 projects for the reporting year was $\$ 744,160,139$, the reported savings represents 7,222 Btu/year for each dollar invested.

Of the 129 projects, 40 reported annual energy savings less than the amount estimated for the period. For these projects, the reported energy savings averages about $82 \%$ of the estimated energy savings.

Sixty-one of the 129 projects reported annual energy savings greater than the amount estimated for the period. On average these projects reported $110 \%$ of the estimated energy savings.

Figure 6 presents reported site energy savings, along with energy savings greater than or less than estimated energy savings. 


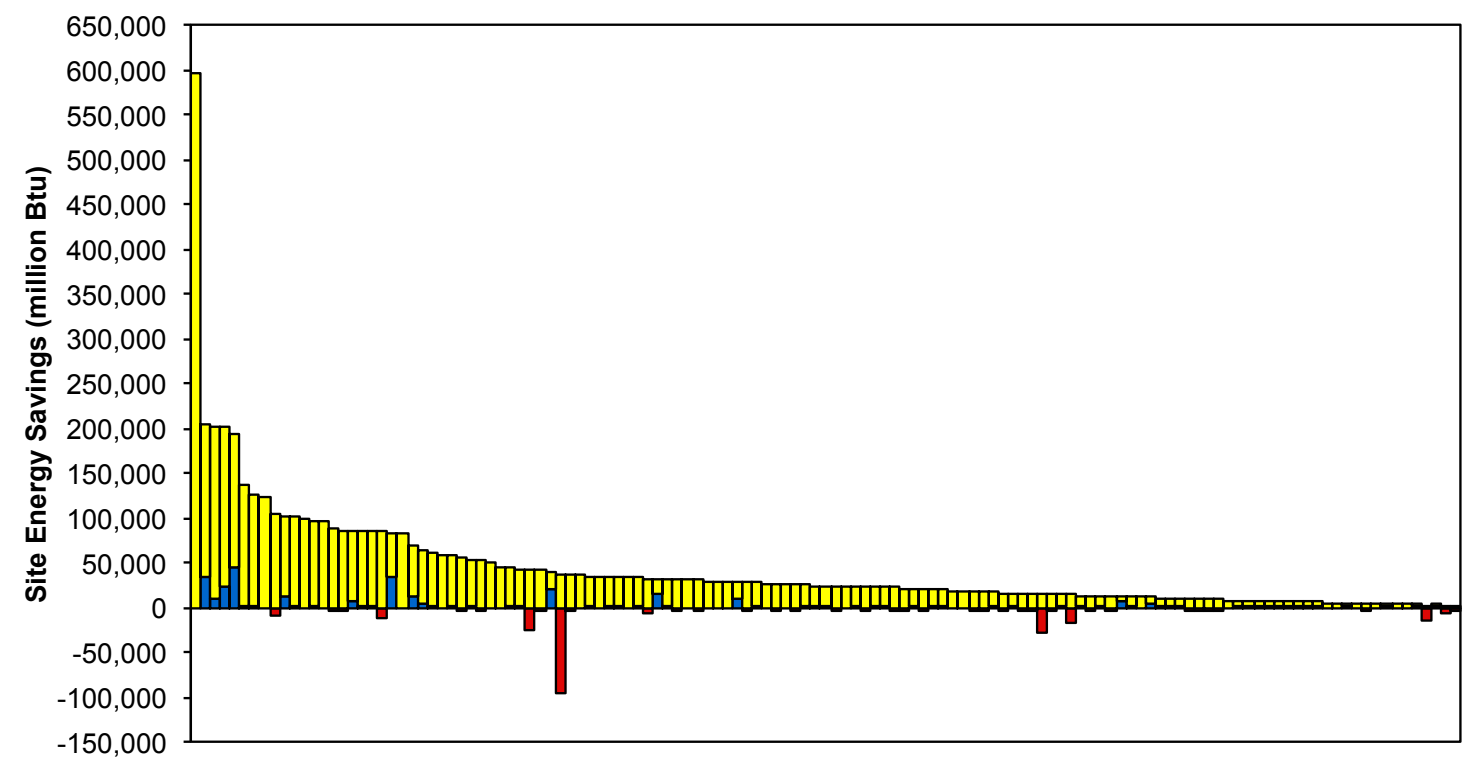

Fig. 6. Annual site energy savings from 129 ongoing DOE ESPC projects. Reported energy savings greater than the estimated savings are shown in blue, and reported energy savings less than the estimated savings are shown in red. Where no shortfall occurs, the yellow bar is the amount of the estimated energy savings. Where a shortfall occurs, the amount of the estimated energy savings is the sum of the heights of the yellow and red bars.

Table 3 presents the net annual reported and estimated energy savings from the 129 projects by fuel type. "Net" savings means that no corrections were made for projects that increased site energy use while reducing source energy use. These numbers are of interest because they present the direct reductions in utility usage at the project sites. Note that the ratio of reported to estimated savings varies by fuel type. In the aggregate, the projects report $97 \%$ of the estimated chilled water savings, but $103 \%$ of the estimated steam savings.

Table 3. Aggregate net annual reported and estimated energy savings by fuel type for 129 DOE ESPC projects

\begin{tabular}{|c|c|c|c|c|c|}
\hline & \multicolumn{2}{|c|}{ Reported } & \multicolumn{2}{|c|}{ Estimated } & \multirow{2}{*}{$\begin{array}{l}\text { Ratio of } \\
\text { reported to } \\
\text { estimated }\end{array}$} \\
\hline & $\begin{array}{l}\text { Savings } \\
\text { (MMBtu) }\end{array}$ & $\begin{array}{c}\text { Percentage } \\
\text { of total }\end{array}$ & $\begin{array}{l}\text { Savings } \\
\text { (MMBtu) }\end{array}$ & $\begin{array}{c}\text { Percentage } \\
\text { of total }\end{array}$ & \\
\hline Electricity & $1,927,717$ & $39.4 \%$ & $1,923,820$ & $39.6 \%$ & 1.00 \\
\hline Natural gas & $1,377,796$ & $28.2 \%$ & $1,409,167$ & $29.0 \%$ & 0.98 \\
\hline Steam & 675,090 & $13.8 \%$ & 657,948 & $13.5 \%$ & 1.03 \\
\hline Fuel Oil & 98,781 & $2.0 \%$ & 96,110 & $2.0 \%$ & 1.03 \\
\hline Chilled water & 16,147 & $0.3 \%$ & 16,753 & $0.3 \%$ & 0.97 \\
\hline Other & 794,969 & $16.3 \%$ & 756,163 & $15.6 \%$ & 1.05 \\
\hline Total & $4,890,527$ & & $4,859,960$ & & 1.01 \\
\hline
\end{tabular}

Energy use can also be reported on the basis of source energy, which accounts for all the energy used at the power plant to produce the electricity delivered to the site. In general, source energy provides a better measure of the environmental impacts of energy efficiency and renewable energy measures than does site energy use. Given the data in Table 3 and an average $28.8 \%$ 
electric conversion efficiency (as specified in DOE's guidance on Section 502(e) of Executive Order 13123), the reported and estimated source energy savings resulting from the 129 projects are 10,405,119 and 10,400,943 MMBtu, respectively. Thus on a source energy basis, reported energy savings is essentially equal to the estimated energy savings - at $100.04 \%$. With the exclusion of a sizable shortfall in one project evident in Figure 7, the ratio of reported to estimated source savings is $101.7 \%$.

Figure 7 presents the source energy savings for each project, along with any additional savings above or shortfalls below the estimated source energy savings.

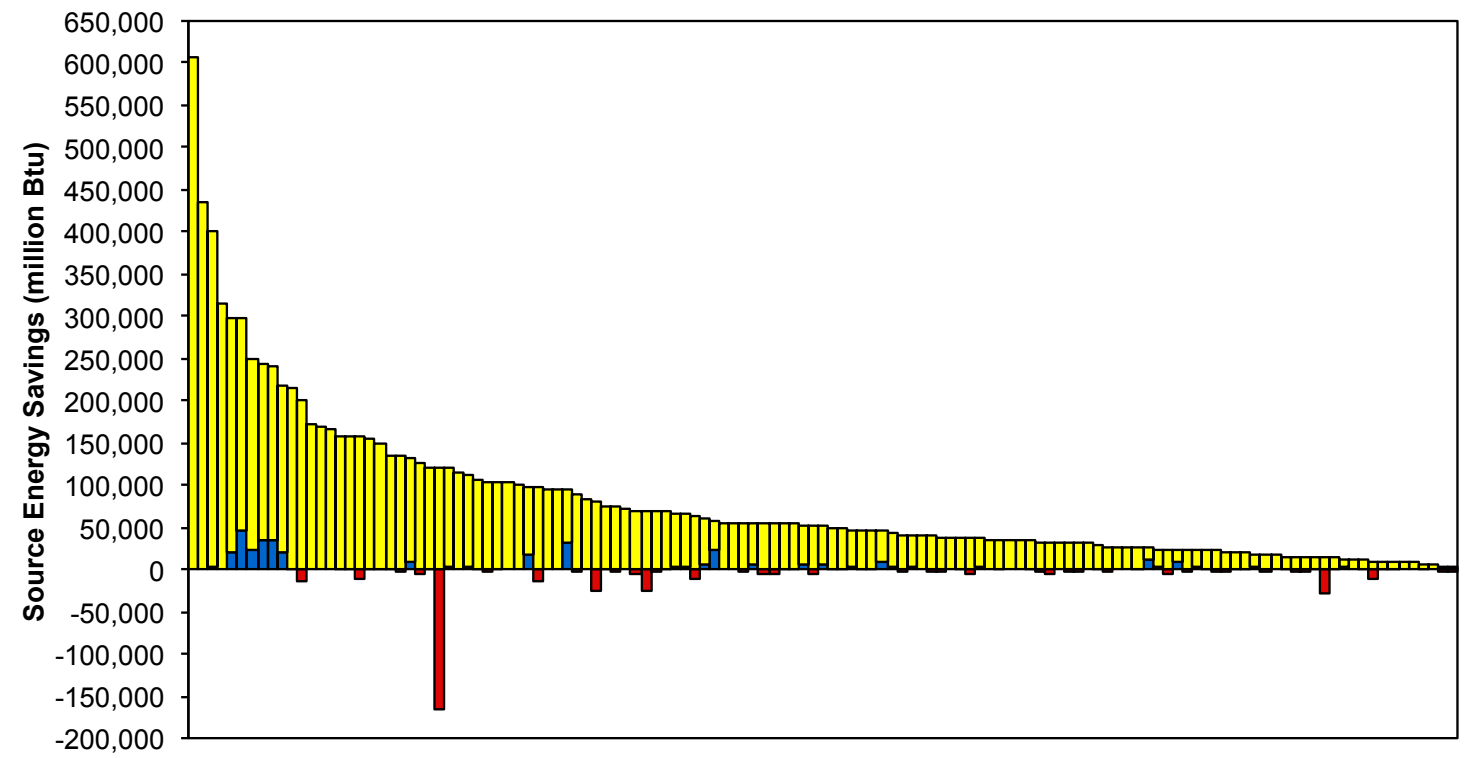

Fig. 7. Annual source energy savingsfrom 129 ongoing DOE ESPC projects Reported energy savings greater than the estimated savings are shown in blue, and reported energy savings less than the estimated savings are shown in red. Where no shortfall occurs, the yellow bar is the amount of the estimated savings. Where a shortfall occurs, the amount of the estimated savings is the sum of the heights of the yellow and red bars.

\section{Energy and Cost Savings by ECM}

Table 4 presents information on the source of energy and cost savings by ECM technology category. The table shows, for example, that $18.1 \%$ of program-wide site energy savings and $17.3 \%$ of program-wide source energy savings are derived from ECMs involving building automation and controls. These ECMs are responsible for $17.0 \%$ of program-wide reported cost savings. 
Table 4. Percent of program-wide reported site energy savings, reported source energy savings, and reported cost savings delievered by each technology category

\begin{tabular}{lrrr}
\hline \multicolumn{1}{c}{ Technology } & $\begin{array}{c}\text { Site energy } \\
\text { savings }\end{array}$ & $\begin{array}{c}\text { Source energy } \\
\text { savings }\end{array}$ & $\begin{array}{c}\text { Reported cost } \\
\text { savings }\end{array}$ \\
\hline Building automation/controls & $18.1 \%$ & $17.3 \%$ & $17.0 \%$ \\
Heating, ventilating, and air conditioning & $14.9 \%$ & $13.4 \%$ & $13.6 \%$ \\
Constant hot water/high-temp hot & & & \\
water/steam distribution & $14.9 \%$ & $9.2 \%$ & $8.8 \%$ \\
Lighting & $13.5 \%$ & $23.1 \%$ & $17.2 \%$ \\
Boiler plant improvements & $8.9 \%$ & $4.9 \%$ & $7.8 \%$ \\
Water and sewer conservation systems & $6.6 \%$ & $3.6 \%$ & $5.2 \%$ \\
Chiller plant improvements & $6.1 \%$ & $6.9 \%$ & $8.6 \%$ \\
Ground-source heat pump & $4.7 \%$ & $3.8 \%$ & $4.4 \%$ \\
Envelope modifications & $3.4 \%$ & $2.0 \%$ & $0.3 \%$ \\
Distributed generation & $3.0 \%$ & $9.3 \%$ & $6.0 \%$ \\
Motors and drives & $1.9 \%$ & $2.7 \%$ & $1.5 \%$ \\
Renewables & $1.5 \%$ & $1.1 \%$ & $1.6 \%$ \\
Energy/utility distribution systems & $0.9 \%$ & $0.7 \%$ & $1.0 \%$ \\
Advanced metering systems & $0.8 \%$ & $1.1 \%$ & $4.4 \%$ \\
Load shifting & $0.6 \%$ & $0.4 \%$ & $0.2 \%$ \\
Process improvements & $0.2 \%$ & $0.4 \%$ & $0.6 \%$ \\
Commissioning & $0.1 \%$ & $0.1 \%$ & $1.4 \%$ \\
Refrigeration & $0.0 \%$ & $0.1 \%$ & $0.1 \%$ \\
Rate adjustments & $0.0 \%$ & $0.0 \%$ & $0.4 \%$ \\
Appliance/plug-load reductions & $0.0 \%$ & $0.0 \%$ & $0.0 \%$ \\
\hline
\end{tabular}

\section{CONCLUSIONS}

In federal ESPC projects, ESCOs use engineering formulas and other techniques to estimate the energy savings that will result from the conservation measures installed. Contract energy prices are then used to estimate the cost savings that will result from the estimated energy savings in each year of the contract. Other cost savings, including those that result from O\&M or R\&R savings, are added in to determine the total estimated annual cost savings. ESCOs then guarantee a percentage of the estimated cost savings. In the M\&V report, the ESCO reports both the energy savings and the cost savings that occurred during the reporting period.

Based on an analysis of the most recent year's M\&V reports from all ongoing projects that have completed at least one year of performance, aggregate reported savings in the DOE ESPC program is about $105 \%$ of aggregate guaranteed cost savings. Aggregate reported savings is about $101 \%$ of the estimated savings. This means that ESCOs are guaranteeing about $96 \%$ of the estimated annual cost savings.

Energy savings can be calculated in terms of site energy use and source energy use. Based on both site and source energy use, the projects analyzed reported $100.0 \%$ of estimated energy savings. When excluding one particular project with a sizeable shortfall, the site and source energy use as a percentage of estimated usage rise to $101.2 \%$ and $101.7 \%$ respectively.

While we did not attempt to verify the energy or cost savings in any way, these results do serve as a first-level measure of the overall performance of the DOE ESPC program. Based on the information reported, the projects appear to be meeting their objectives in terms of energy and cost savings. 


\section{APPENDIX A}

Section 502(e) Guidance Providing Credit Toward Energy Efficiency Goals for Cost-Effective Projects Where Source Energy Use Declines But Site Energy Use Increases 


\section{Section 502(e) Guidance \\ Providing Credit Toward Energy Efficiency Goals for Cost-Effective Projects Where Source Energy Use Declines But Site Energy Use Increases (Amended October 1, 2004)}

\section{Background}

Section 502(e) of Executive Order 13123 requires the Secretary of Energy to "issue guidance for providing credit toward energy efficiency goals for cost-effective projects where source energy use declines but site energy use increases."

Section 206 of the Executive Order states:

Source Energy. The Federal Government shall strive to reduce total energy use and associated greenhouse gas and other air emissions, as measured at the source. To that end, agencies shall undertake life-cycle cost-effective projects in which source energy decreases, even if site energy use increases. In such cases, agencies will receive credit toward energy reduction goals through guidelines developed by DOE.

Energy measured at the point of use is termed "site energy." Energy measurement that accounts for the generation, transmission and distribution of the energy is called "source energy." Whichever way consumption is measured, cost-effectiveness remains the mandated criteria for assessing, selecting, and funding potential Federal energy efficiency projects. In June 1996, the Federal Interagency Energy Policy Committee (656 Committee) unanimously approved a policy statement that encourages cost-effective energy projects that result in reduced energy consumption regardless of whether that consumption is measured on a site basis or source basis.

The Department of Energy's Annual Report to Congress on Federal Government Energy Management will continue to report facility consumption both ways on an agency-wide basis and refers to source-measured energy as primary consumption and site-measured energy as net consumption. When tracking performance toward the mandated reduction goals for buildings and facilities, Btu per gross square foot will be measured on a site basis, while source-measured consumption is also reported in accompanying tables.

Agencies should continue to report energy consumption as in the past, i.e., aggregated and submitted in the following units for each energy type.

$\begin{array}{ll}\begin{array}{l}\text { Energy Type } \\ \text { Electricity }\end{array} & \begin{array}{l}\text { Reporting Unit } \\ \text { (Megawatt Hours) }\end{array} \\ \text { Fuel Oil } & \text { (Thousands of Gallons) } \\ \text { Natural Gas } & \text { (Thousand Cubic Feet) } \\ \text { LPG/Propane } & \text { (Thousands of Gallons) } \\ \text { Coal } & \text { (Short Ton) } \\ \text { Purchased Steam } & \text { (Billion Btu) } \\ \text { Other } & \text { (Billion Btu) }\end{array}$

Site Conversion Factor

3,412 Btu/kilowatt hour 138,700 Btu/gallon $1,031 \mathrm{Btu} / \mathrm{cubic}$ foot 95,500 Btu/gallon 24,580,000 Btu/short ton $1,000 \mathrm{Btu} /$ pound 
Based on these submissions DOE will calculate energy consumption in site-delivered Btu and Btu per gross square foot. DOE will also calculate Btu per gross square foot on a source basis.

Based on agency reporting for projects that reduce source energy use although site energy use increases, DOE will credit the source energy savings to the agency site energy use before the final calculation of goal performance in terms of site Btu per gross square foot.

Agencies may apply the credit themselves when reporting their performance to the Office of Management and Budget on their Agency Energy Scorecards.

\section{Calculating Project-Specific Source Energy Reductions}

Agencies can receive credit on their scorecard evaluations for life-cycle cost-effective projects where source energy declines and site energy increases. For each such completed project, agencies should calculate source energy savings for the reported fiscal year. Agencies may use the national average source conversion factors used by DOE or may choose factors for their state, utility, or steam provider. The national conversion factors used by DOE are:

\section{Electricity $\quad 11,850 \mathrm{Btu} /$ kilowatt hour \\ Purchased Steam 1,390 Btu/pound}

The electricity conversion factor includes energy lost in the generation process $(66.5 \%)$, electricity used in the utility plant (1.7\%), electricity lost in the transmission and distribution process $(3.0 \%)$, and electricity delivered to the customer's site $(28.8 \%)$. If a project uses a different factor, the source and each of these components should be documented along with the corresponding project worksheet.

Agencies should use the following worksheet to document, for each applicable project, that source energy is reduced but site energy increases, and therefore the project qualifies for the Section 502(e) credit:

\begin{tabular}{|c|c|c|c|}
\hline & $\begin{array}{l}\text { PROJECT WORKSHEE } \\
\text { (Include ID of project and date c } \\
\text { Base Case (without Project) }\end{array}$ & & $\begin{array}{c}\text { EXAMPLE: } \text { XYZ } \\
\text { Project aaa }\end{array}$ \\
\hline Line 1 & Annual Source Energy Used & MMBtu & 225,900 MMBtu \\
\hline Line 2 & Annual Site Energy Used & MMBtu & 107,770 MMBtu \\
\hline Line 3 & $\begin{array}{l}\text { With Project } \\
\text { Annual Source Energy Used }\end{array}$ & MMBtu & 178,800 MMBtu \\
\hline Line 4 & $\begin{array}{l}\text { Annual Site Energy Used After Project } \\
\text { (subtract Line } 3 \text { from Line 1 this is:) }\end{array}$ & MMBtu & $\overline{128,170}$ MMBtu \\
\hline Line 5 & $\begin{array}{l}\text { Annual Source Energy Saved After Proj. } \\
\text { (subtract Line } 2 \text { from Line } 4 \text {, this is:) }\end{array}$ & MMBtu & 47,100 MMBtu \\
\hline Line 6 & Annual Site Energy Increase After Proj. & MMBtu & 20,400 MMBtu \\
\hline
\end{tabular}


Qualifying projects receive a credit in the amount of the annual source energy savings (line 5 above), which is used to adjust downward the agency site energy use before the final calculation of goal performance in terms of site Btu per gross square foot. However, since qualifying projects have the characteristic that on-site utilization of energy forms other than electricity increase, while purchases of grid electricity are reduced; the agency's existing site energy use tracking system (e.g., the Defense Utility and Energy Reporting System for the Navy) will automatically recognize part of the credit. The purpose of the 502(e) adjustment is to account for the rest of the source energy savings credit.

For example, consider a large cogeneration (combined heat and power or CHP) project. Electricity is generated on-site with natural gas backed up with liquid fuel, and heat is recovered from the generation process and recycled to reduce purchases of boiler fuels, and/or to generate chilled water, further reducing grid electricity purchases. As a result of the project, fuel use for on-site power generation increases, fuel use for boilers decreases, and grid electricity purchases decrease. Site Btu and source Btu are substantially identical for all energy forms impacted by the project except for grid electricity, where $1 \mathrm{kWh}$ equals 11,850 source Btu (national average) but only 3,412 site Btu. With the exception of grid electricity, all forms of energy affected by the project have the same Btu value whether site or source. Therefore, backing out the grid electricity displaced by the project (self-generation, electric chiller load displaced by chilled water from recycled heat, etc.), on a source-Btu basis, is all that needs to be done. The agency's site energy tracking system will already have backed out displaced grid electricity because it no longer appears on the utility meter, but only at a rate of 3,412 Btu per kWh. An adjustment is needed to account for the rest of the source energy savings, at a rate of $8,438 \mathrm{Btu}$ per $\mathrm{kWh}$ $(11,850$ minus 3,412$)$. The 502(e) adjustment for the cogeneration project equals the displaced grid electricity in $\mathrm{kWh}$ per year multiplied by 8,438 Btu per $\mathrm{kWh}$.

After calculating adjustments for each qualifying project, compile the data into the Compilation Worksheet format below:

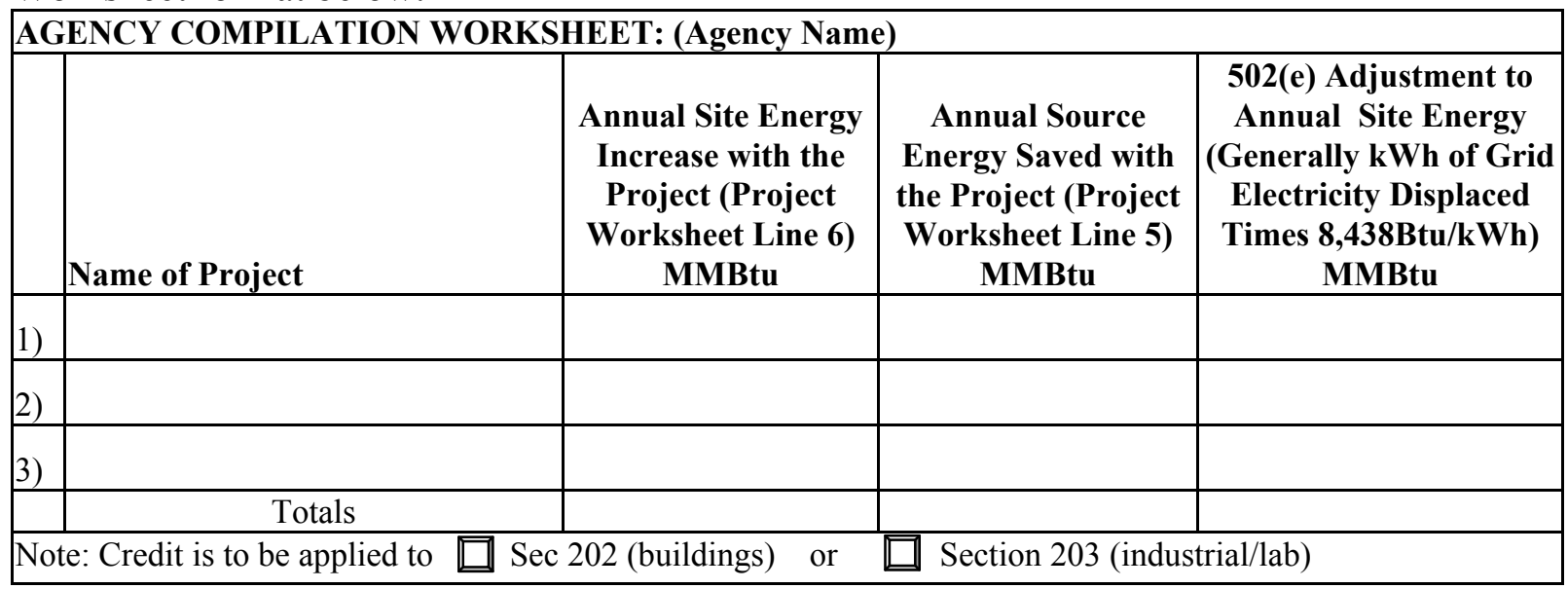

In the table above, the right hand column total will be subtracted from the agency's total site energy use for buildings subject to the Section 202 goal, or from the agency's total site energy use for industrial/lab areas subject to the Section 203 goal, whichever the case may be, before calculating site Btu-per-gross-square-foot. 


\section{Submission to DOE}

Agencies should submit their Compilation Worksheets to DOE to assure that the adjusted site energy is documented. Project data should be submitted for Section 202 and Section 203 on separate forms. Agencies need to submit their compilation sheet(s) for each year of their projects' lives so they can continue to get credit for all operating projects completed in previous years.

Additional Benefits and Recognition of Projects that Reduce Source Energy

(1) Impact on Greenhouse Gas Reduction Goal: Progress toward the new greenhouse gas reduction goal will be calculated based on source-measured energy. Therefore, projects that result in source energy reductions will directly contribute to an agency's performance toward the greenhouse gas reduction goal of Section 201 of the Order.

(2) Reductions in Source Energy per Gross Square Foot: Agency progress toward energy reduction goals will be tracked in the Annual Report to Congress on Federal Government Energy Management on a source-measured basis as well as on a site-measured basis. This will highlight agency achievements in source energy reductions as directed under Section 206 of the Order.

[Note: This guidance will be incorporated into the annual DOE Reporting Guidance for the Annual Report to Congress on Federal Government Energy Management.] 